\title{
Ehlers-Danlos syndrome has varied molecular mechanisms
}

\author{
F Michael Pope, Nigel P Burrows
}

Ehlers-Danlos syndrome (EDS) is a group of variable clinical entities which share a propensity to skin fragility, joint laxity, and ligamentous fragility or shortening. Tschernogobow, ${ }^{1}$ Ehlers, ${ }^{2}$ and Danlos ${ }^{3}$ independently described unusual bruising, excessive cutaneous extensibility, and molluscoid pseudotumours. The eponym of Ehlers-Danlos syndrome (EDS) was first suggested by Poumeau-Delille and Soulie. ${ }^{4}$ Spectacular early examples were retrospectively commented upon by Beighton. ${ }^{5}$ Morris $^{6}$ described a notable British patient who Beighton re-examined more than 60 years later. The proband had classical EDS. Beighton ${ }^{7}$ not only showed impressive pictures of the so-called "Elastic Lady" but also included the original lithograph of a Spaniard with unilateral cutaneous hyperextensibility investigated in Leyden almost 300 years before, who was very probably a somatic mosaic. In Ehlers's time there was considerable difficulty in distinguishing clearly between cutis hyperelastica (overextensible skin), dermatorrhexis (easy splitting of skin), and both localised and generalised dermatochalasis (pendulous or redundant skin). To this day the similarities of such physical signs still cause confusion. In practice the designations hyperelastic, pendulous, and lax skin often overlap and can even occur at different times in the same patient. For example, EDS skin is hyperelastic early in life but later becomes lax or drooping, especially in old age. The systemic implications, complications, and associations of EDS were largely unrecognised for many years although the association of congenital hip dislocations was described early. In 1960 Mories $^{8}$ first described a four-fold increase in fetal prematurity. He also noticed that the dermis was collagen depleted and elastin rich. Thirdly, he described catastrophic lethal arterial bleeding in a 15 year old adolescent boy with a traumatic arterial tear which was surgically unrepairable because of the extreme venous and arterial fragility. Very probably the patients with prematurity had EDS I/II while the vascular fragility was caused by acrogeric EDS IV. Subsequent clinical, molecular, and genetic progress has been rapid. For example, Barabas ${ }^{9}$ first proposed three distinct subsets. These included classical forms with prematurity, a milder type with venous varicosity, and a third, potentially lethal, form with minor cutaneous and joint changes but extreme arterial fragility (which we now call EDS IV). Soon afterwards, Beighton ${ }^{10}$ also clearly described the frequent prematurity. $\mathrm{He}$ added an X linked form, ${ }^{11}$ while dividing Barabas's first group into "gravis" and "mitis" variants, which we now call EDS I and II respectively, to make five subtypes. $\mathrm{He}$ also delineated the wide clinical heterogeneity with various rheumatological, orthopaedic, surgical, and cutaneous complications and was also fully familiar with such surgical complications as arterial aneurysms, venous varicosities, arteriovenous fistulas, and inguinal, umbilical, and hiatus hernias. He also documented reflux hydronephrosis, bladder neck obstruction, colonic diverticulae with perforation, and pleuroperitoneal rupture (leading to pneumo- or haemothorax). These complications are now recognised as particularly common in EDS types IV, VI, and VII. In 1972, McKusick ${ }^{12}$ added two further subtypes (types VI and VII). We now know that the former is caused by lysyl underhydroxylation, while the latter results from the misprocessing of procollagen (to collagen). In 1988 Beighton et $a l^{13}$ published an International Nosology of Connective Tissue Disease where nine subcategories of EDS were defined. Subsequently, he correlated the subtypes with the various biochemical and molecular abnormalities (table 1) and also published the equivalent Molecular Nosology. ${ }^{14}$ ( 7 Med Genet 1997;34:400-410)

Keywords: Ehlers-Danlos syndrome; molecular mechanisms

\section{Genetics of EDS (table 1)}

Autosomal dominant or autosomal recessive inheritance occurs in EDS I, II, III, IV, VI, and VII. Compound heterozygosity (see later) is also very likely. $\mathrm{X}$ linked forms have been described but are highly unusual. Autosomal dominant inheritance was first mentioned by Kopp. ${ }^{15}$ Wiener $^{16}$ described 12 affected subjects in three generations. Stuart ${ }^{17}$ and Coe and Silver ${ }^{18}$ both described the vertical transmission particularly of EDS type I. Johnson and Falls ${ }^{19}$ published a very large five generation American family of British-Canadian extraction with typical EDS I and with two separate 
homozygotes. They also speculated upon autosomal recessive inheritance while both Weber and Aitken $^{20}$ and Ronchese ${ }^{21}$ separately described sporadic examples of EDS I with affected first cousin parents.

Autosomal recessive inheritance occurs in EDS VI although compound allelic heterozygosity may be more common than homozygosity except in consanguineous or inbred populations. Beighton ${ }^{5}$ first suggested autosomal recessive inheritance in an affected brother and sister whose parents and children were normal. Convincing autosomal recessive inheritance also occurs in procollagen peptidase deficiency. In humans this causes EDS VIIC and in animals dermatosparaxis. While the animal skin is excessively fragile, in humans there is extreme joint laxity and blepharochalasis/cutis laxa (CL). The original EDS VII patient of Lichtenstein et $a l^{22}$ had congenital hip dislocations and short stature. Skin from EDS VIIC patients, cattle, sheep, and cats show severely disorganised and misassembled hieroglyphic collagen fibrils when examined by transmission electron microscopy. Homozygosity or double heterozygosity has also been postulated in EDS IV. ${ }^{123-25}$ The latter patient had a normal collagen III profile. The family of Beasley and Cohen ${ }^{26}$ with joint laxity, lop ears, and an unusual face may also be an example of autosomal recessive inheritance but was unclassifiable clinically. Apparent X linked pedigrees were documented by Beighton ${ }^{11}$ in two British families with a clinical phenotype resembling EDS II. One family contained six affected males and three possible carrier females in four genera- tions. Phenotypic variability is far outweighed by biochemical and molecular diversity so that individual families are (almost always) unique. An International Working Party was convened to standardise the nosology ${ }^{13}$ and EDS IX (the occipital horn syndrome) and EDS XI (familial joint instability) are now excluded from the classification. Lysyl oxidase deficiency is associated with Menkes syndrome and X linked cutis laxa which, while allelic, are not a form of EDS. The lysyl oxidase dependent form of EDS has not been confirmed.

\section{Molecular abnormalities causing EDS (table 1)}

In keeping with recent rapid advances, the molecular mechanisms of many EDS subtypes are now well understood. Most disrupt collagen fibril assembly by altering certain crucial molecular components, the anatomical distribution of which dictates the consequent molecular pathology. Thus the molecular composition of regions such as skin, vasculature (arteries, veins, and capillaries), pleuroperitoneum, intestinal walls, ligaments, tendons, cartilage, and eyes (the cornea and vitreous) may be severely weakened and disorganised.

Many types of EDS have specific mutations, while in others, such as EDS III, VIII, and X, the abnormality is either unknown or inconsistent. Generally, there are two classes of mutations, one in which structural genes are faulty and the other in which their processing enzymes are disturbed. ${ }^{27}$ Examples of the former are mutations of the COL1A1, 1A2, $3 \mathrm{~A} 1$, and $5 \mathrm{~A} 1$ genes and of the latter lysyl

Table 1 Ehlers-Danlos syndrome (cutis hyperelastica) after Beighton et al ${ }^{13}$

\begin{tabular}{|c|c|c|c|c|c|}
\hline Type & Synonym & McKusick No & Special features & $\begin{array}{l}\text { Histology electron } \\
\text { microscopy }\end{array}$ & Basic defect \\
\hline EDS I & Gravis type & $\mathrm{AD} 130000$ & $\begin{array}{l}\text { Widespread scarring and } \\
\text { bruising, especially forehead, } \\
\text { chin, and shin. Molluscoid } \\
\text { pseudotumours }\end{array}$ & $\begin{array}{l}\text { Cauliflower } \\
\text { fibrils }\end{array}$ & $\begin{array}{l}\text { COL5A1 linked in some } \\
\text { families. Mutations } \\
\text { include exon skips and a } \\
\text { translocation and a } \\
\text { cysteine substitution }\end{array}$ \\
\hline EDS II & Mitis type & $\mathrm{AD} 130010$ & Similar but less severe & $\begin{array}{l}\text { Cauliflower } \\
\text { fibrils }\end{array}$ & \\
\hline EDS III & $\begin{array}{l}\text { Hypermobile } \\
\text { type }\end{array}$ & $\mathrm{AD} 130020$ & No cutaneous scars & Non-specific & Unknown \\
\hline \multirow[t]{4}{*}{ EDS IV } & Vascular type & \multirow[t]{2}{*}{$\mathrm{AD} 130050$} & \multirow{3}{*}{$\begin{array}{l}\text { Nearly always type III collagen } \\
\text { deficient }\end{array}$} & \multirow{5}{*}{$\begin{array}{l}\text { Collagen } \\
\text { depletion, } \\
\text { variation of fibre } \\
\text { size }\end{array}$} & \multirow{5}{*}{$\begin{array}{l}\text { COL3A1 mutations. } \\
\text { Numerous point } \\
\text { mutations and exon skips, } \\
\text { rarely deletions }\end{array}$} \\
\hline & IVA acrogeric & & & & \\
\hline & IVB acrogeric & AR 22535 & & & \\
\hline & IVC ecchymotic & $\mathrm{AD} 130050$ & $\begin{array}{l}\text { Risk of arterial rupture highest in } \\
\text { acrogeric subtypes }\end{array}$ & & \\
\hline EDS V & $\mathrm{X}$ linked type & XL 305200 & $\begin{array}{l}\text { Very rare. Not lysyl oxidase } \\
\text { deficient. Resembles EDS I, II, } \\
\text { and III }\end{array}$ & & \\
\hline \multirow[t]{2}{*}{ EDS VI } & $\begin{array}{l}\text { Ocular scoliotic } \\
\text { VIA decreased } \\
\text { lysyl hydroxylase } \\
\text { levels }\end{array}$ & \multirow[t]{2}{*}{ AR 225400} & $\begin{array}{l}\text { Muscular hypotonia, often } \\
\text { muscular dystrophy suspected } \\
\text { (slow motor milestones) }\end{array}$ & \multirow[t]{2}{*}{ Non-specific } & \multirow[t]{2}{*}{$\begin{array}{l}\text { Lysyl hydroxylase point } \\
\text { mutations or exon skips } \\
\text { (homozygosity and } \\
\text { double heterozygosity) }\end{array}$} \\
\hline & $\begin{array}{l}\text { VIB normal } \\
\text { levels }\end{array}$ & & $\begin{array}{l}\text { Persistent premature scoliosis. } \\
\text { Arterial rupture in } 30 \%\end{array}$ & & \\
\hline \multirow[t]{2}{*}{$\begin{array}{l}\text { EDS VII } \\
\text { A, B, C }\end{array}$} & \multirow[t]{2}{*}{$\begin{array}{l}\text { Arthrochalasis } \\
\text { multiplex } \\
\text { congenita }\end{array}$} & $\mathrm{AD} 130060$ & $\begin{array}{l}\text { Extremely lax joints with } \\
\text { congenital hip dislocation. } \\
\text { Occasionally mild facial cutis } \\
\text { laxa. Some types have skin } \\
\text { fragility, mandibular hyperplasia }\end{array}$ & \multirow[t]{2}{*}{$\begin{array}{l}\text { Fibrils vary from } \\
\text { angular in A and } \\
B \text {, to } \\
\text { hieroglyphic in } C\end{array}$} & \multirow{3}{*}{$\begin{array}{l}\text { Types A \& B specific } \\
\text { exon } 6 \text { skips or deletions } \\
\text { of COL1A1, 1A2 either } \\
\text { pNa } 1(\mathrm{I}) \text { or } \mathrm{pN} \alpha 2(1) \\
\text { retained. Type C } \\
\text { procollagen peptidase } \\
\text { deficiency. Both pNa } 1(\mathrm{I}) \\
\text { and pN } 2 \text { (I) extensions } \\
\text { retained } \\
\text { Some are COL3A1 } \\
\text { others not }\end{array}$} \\
\hline & & AR 224510 & $\begin{array}{l}\text { Severe generalised cutis laxa in } \\
\text { humans; dermatosparaxis in } \\
\text { cattle, sheep, and cats }\end{array}$ & & \\
\hline EDS VIII & $\begin{array}{l}\text { Periodontitis } \\
\text { type } \\
\text { Vacant }\end{array}$ & AD 130080 & $\begin{array}{l}\text { Allelic variation with variable } \\
\text { expression }\end{array}$ & Non-specific & \\
\hline EDS $\mathrm{x}$ & $\begin{array}{l}\text { Fibronectin } \\
\text { abnormality }\end{array}$ & AR 225310 & Fibronectin deficient & & $\begin{array}{l}\text { Association with FN may } \\
\text { be coincidental }\end{array}$ \\
\hline
\end{tabular}




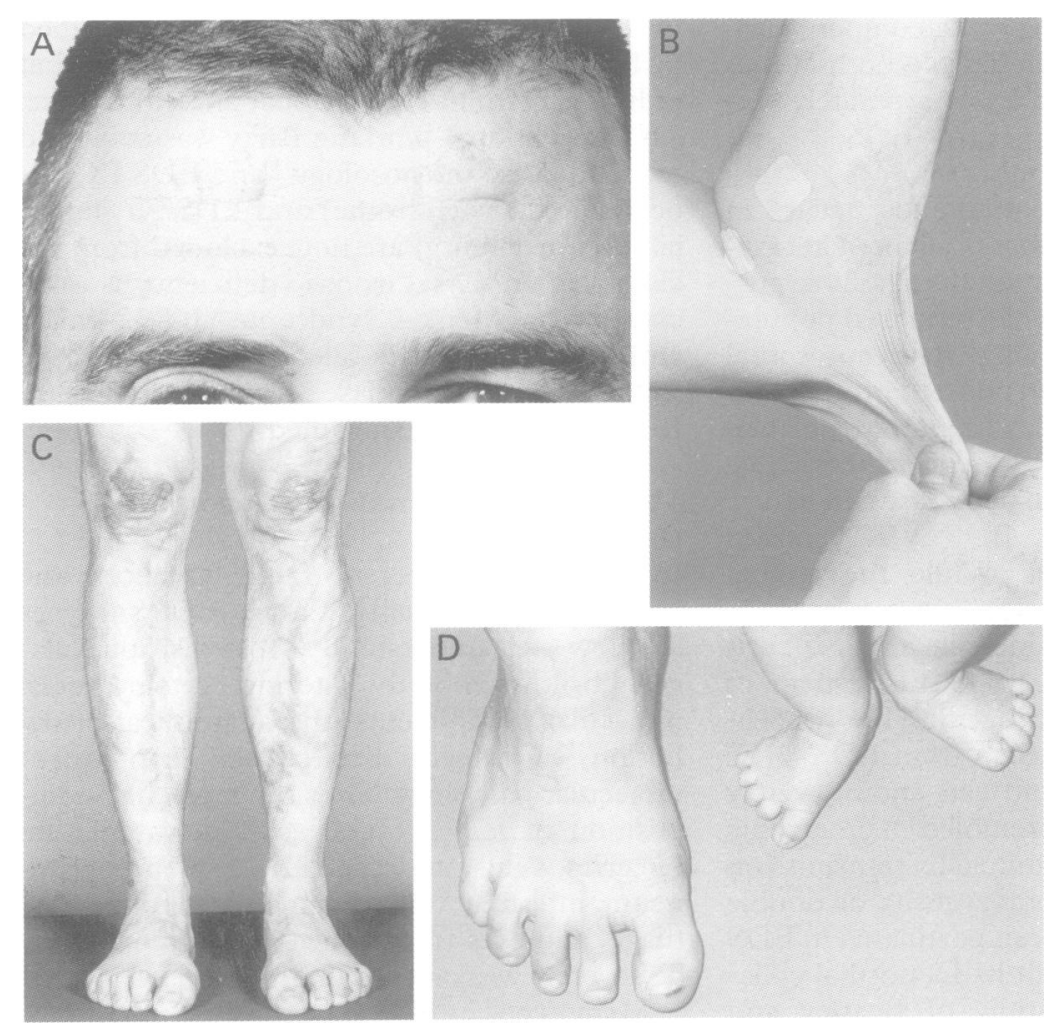

Figure 1 Typical clinical features of EDS I; the clinical signs of EDS II are similar but milder. Shown are the characteristic facial scars $(A)$, extreme cutaneous extensibility $(B)$, and patellar and pretibial scars $(C)$. Broadened feet and hands are also a feature in some families, as shown in this affected father and child (D).

hydroxylase or procollagen peptidase deficiency. Defects of one or other mechanism occur in EDS types I, II, IV, VI, and VII. EDS III, in contrast, is highly heterogeneous clinically and overlaps with osteogenesis imperfecta (OI), pseudoxanthoma elasticum (PXE), and Marfan syndrome (MFS). Candidate genes include COL1A1, 1A2, 3A1, 5A1, fibrillin, elastin, lysyl oxidase, and lysyl hydroxylase.

\section{Clinical features of EDS types I and II (fig 1)}

The five cardinal clinical elements of EDS include hyperextensible, doughy skin, atrophic scars, joint hypermobility, connective tissue fragility, and bruising (table 1). The clinical phenotypes of EDS I and II overlap substantially and are probably allelic autosomal dominant mutations with variable penetrance. Compound heterozygosity is also possible. EDS type I differs from type II only in the degree of skin fragility and ligamentous laxity. The skin splits over prominences such as the forehead, chin, elbows, knees, and shins. Broadened hands and feet and a wide body build (mesomorphism) are also common. Other notable clinical signs include epicanthic folds and fibrous nodules of the knees, shins, and Achilles tendons. Even though mitral valve prolapse is common, aortic dilatation and rupture are not, and arterial fragility is virtually unknown. Non-specific features include cutaneous varicosities, myopia, and late onset osteoarthritis (OA). Since collagen $\alpha 1(V)$ chains occur in cartilage and vitreous humour, the $O A$ is probably a direct complication rather than primarily mechanical. In EDS II the clinical phenotype is milder and skin fragility much less impressive; epicanthic folds, fibrous nodules, and mesomorphism are infrequent or even absent.

\section{Collagen type $\mathrm{V}$ and the role of COL5A1/COL5A2 genes}

There is now strong evidence to implicate type $V$ collagen $\alpha 1$ chains in the aetiology of EDS I and II. Clinical features include excessive skin fragility, ligamentous laxity, and relatively benign prognosis. The collagen is disorganised and forms so-called cauliflower fibrils.

Like collagens I, II, III, and XI, collagen V has an uninterrupted triple helix with $\mathrm{N}$ and $\mathrm{C}$ terminal extensions. There are two or possibly three forms of collagen $\mathrm{V}$ proteins, at least two of which, $\alpha 1(\mathrm{~V})$ and $\alpha 2(\mathrm{~V})$, are coded by separate non-allelic genes. Firstly, on clinical grounds, there are very severely disorganised collagen fibrils (cauliflowers) (fig 2D). Secondly, abnormalities of both collagen type $\mathrm{V} \alpha 1$ chains and the COL5A1 gene have been described in a sporadic EDS I/II patient with increased skin fragility and joint laxity with corneal flattening. ${ }^{28}{ }^{29}$ Furthermore, transgenic homozygous mutant mice with an in frame exonic deletion in $\mathrm{Col} 5 \mathrm{a} 2^{30}$ also had fragile skin, dermal thinning, and corneal disorganisation as well as severe skeletal and ligamentous deformities. An equivalent rabbit model shows similar pathology. Several independent groups have detected linkage of human COL5A1 markers in families with EDS I or II which are therefore allelic. ${ }^{31}{ }^{32}$ Other COL5A1 mutations have also recently been reported. ${ }^{33-35}$ In one, a translocation interrupts the COL5A1 gene at intron $24^{33}$ and in the second an exon 65 skip was found in a three generation family. ${ }^{34} \mathrm{~A}$ third had a mutation of a highly conserved $\mathrm{C}$ terminal cysteine. ${ }^{35}$ There are therefore at least three published COL5A1 mutations with either EDS I or II phenotypes. In other similar families, linkage to COL5A1 has been excluded $^{36}$ (Burrows et al, unpublished data). Somehow, collagen type V controls type I collagen fibril packing. ${ }^{37-41}$ This credibly explains the gross fibrillar disorganisation which typifies EDS I and II and implies that the disorganisation is a direct effect of the mutant type $\mathrm{V}$ collagen. Allegedly, collagen type XI analogously regulates the thickness of collagen type II fibrils and collagen V and XI coassociate with or even substitute for one another in vitreous humour. Corneal shape is also collagen $\mathrm{V}$ dependent. Mutations of either collagen type XI gene (COL11A1 or COL11A2) can cause variants of the Stickler syndrome (SS) ${ }^{42} 43$ in humans and mice. ${ }^{44}$ Since COL11A1 but not $11 \mathrm{~A} 2$ is expressed in the vitreous, only mutations of the former cause vitreous pathology. Collagen $\alpha 2(\mathrm{~V})$ chains coassociate with $\alpha 2(\mathrm{XI})$ chains, ${ }^{45}$ which may both coassociate with collagen type II. It is therefore not surprising that corneal or vitreous abnormalities and high myopia cosegregate with premature OA in some EDS families. Furthermore, COL5A2 mutations are a potential cause of arterial fragility, ${ }^{28}$ suggesting the possibility that $\alpha 2(\mathrm{~V})$ chains and collagen type III interact analogously to $\alpha 1(\mathrm{~V})$ chains and type I collagen chains. Lastly, several 

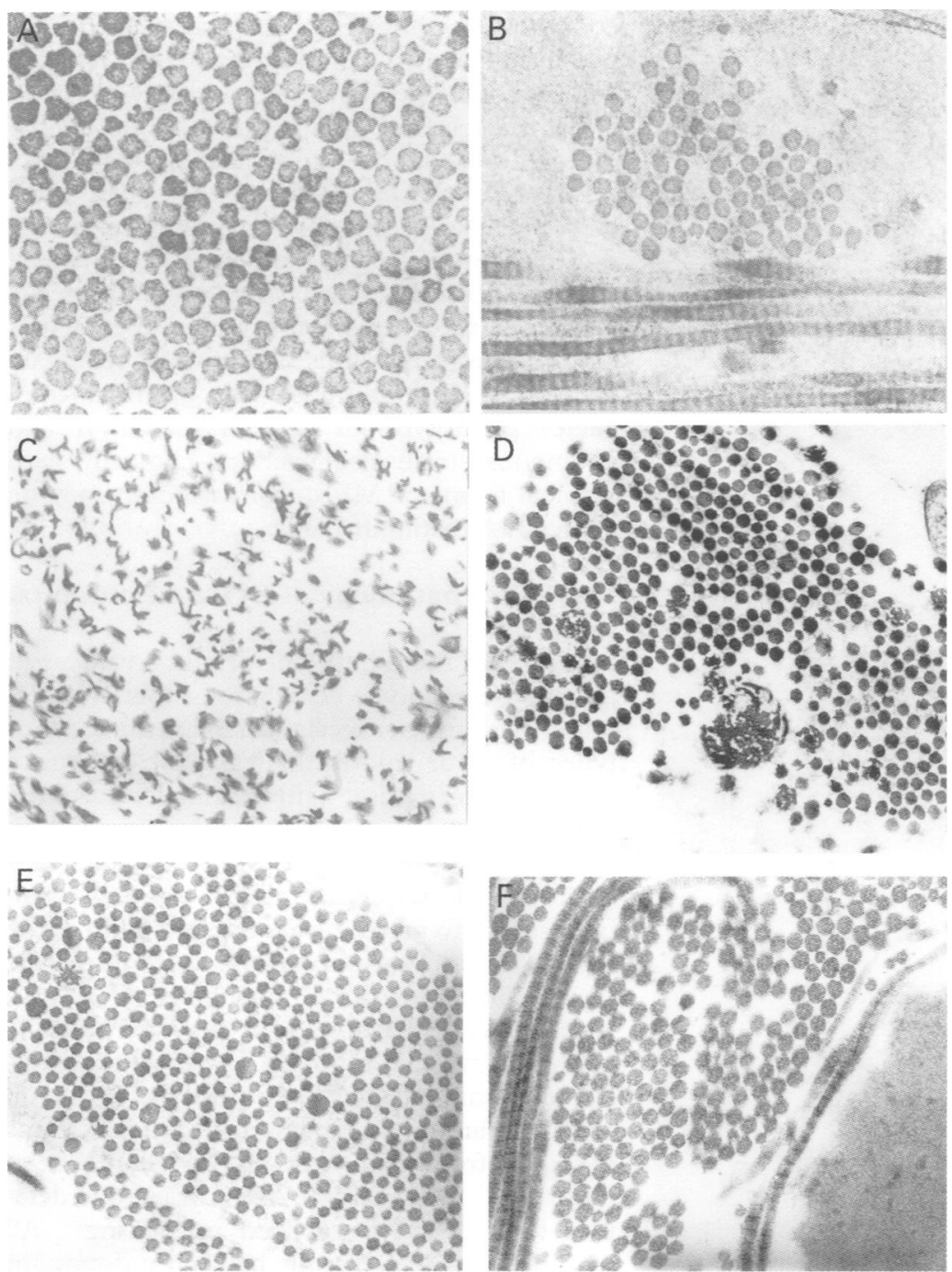

Figure 2 Transmission electron micrographs showing variably angular and hieroglyphic fibrils of (A) EDS VIIA, (B) EDS VIIB, (C) EDS VIIC. The distortion is greatest in EDS VIIC in which every collagen a chain has a persistent $N$ terminal extension. (D) Cauliflower fibres typical of EDS I/II. (E) Irregular fibrils of EDS IV. (F) Normal control showing (to the left) a uniformly sized, transversely sectioned collagen fibril. Fig $2(A)$ and (B) are reproduced by permission of the authors ${ }^{81}$ and the fournal of Medical Genetics, fig $2(B)^{118}$ by permission of the British fournal of Dermatology. We thank Professor Brian Lake of the Institute of Child Health for providing fig 2(C).

different collagen mutations cause disordered fibrillogenesis in vivo. ${ }^{46}$ COL5A1 homozygotes are either exceptionally rare or genetic lethals. Good animal models for COL5A1 mutation will be essential for the future detailed analysis of the chemical composition and 3D organisation of tissues such as articular cartilage, ligament, cornea, vitreous humour, arteries, veins, and capillaries.

\section{Clinical features of EDS type IV (vascular} Ehlers-Danlos syndrome) (fig 3)

Vascular/arterial EDS differs from other varieties by virtue of severe vascular fragility, both venous and arterial. It was originally described by Barabas ${ }^{9}$ and Sack. ${ }^{47}$ In ecchymotic EDS there are often post-haemorrhagic haemosiderin deposits over the knees, shins, and elbows, which may also complicate EDS I/II and VIII. Acrogeria is specific to EDS IV and is characterised by generally thinned skin; the extremities (hands, feet, and face) are prematurely aged (fig 3A, B). Other suggestive features include prominent capillaries and kel- oidal or elastotic scars (often with elastosis perforans serpiginosa). Large eyes, lobeless ears, and a Madonna-like face are also typical. ${ }^{48}$ Although short stature is usual, occasional slim and tall people overlap with MFS. Other clinical features include acro-osteolysis, diffuse alopecia of the scalp, and certain orthopaedic complications such as congenital talipes or hip dislocations and tendon contractures, particularly of the Achilles or extensor tendons of the feet and toes. Pleuroperitoneal or colonic rupture are more non-specific (and may also complicate other EDS or MFS phenotypes). Vascular pathology includes aneurysms of small to medium sized arteries such as renal, splenic, axillary, brachial, femoral, popliteal, and internal carotid vessels. The internal carotid system may be compromised by dilatation, arteriovenous malformations, aneurysms, or dissections caused by arterial thinning and fragility from collagen III deficiency. Occasionally the general phenotype is EDS III/BHS. ${ }^{48} 49$ For example, we observed a Gly $\rightarrow$ Ser 637 substitution in a large autosomal dominant pedigree with generalised joint laxity and premature osteoarthritis. ${ }^{48} 49$

In EDS IV, skin histology shows striking dermal thinning (from one-third to two-thirds of normal), collagen depletion, and elastin proliferation. The mechanism of the latter is unclear (and may be primary rather than secondary to collagen depletion). Transmission electron microscopy typically shows collagen fibril disorganisation with irregularity and a bimodal size distribution (fig 2E). Somehow collagen III/I ratios influence collagen fibril diameter and interactions and, if mutated or diminished, seriously impair long term arterial strength and stability.

\section{Protein chemistry}

There is very strong clinical, histological, biochemical, and molecular evidence that faulty collagen III causes dermal atrophy and vascular and gastrointestinal fragility. ${ }^{23} 2427$ Firstly, collagen III predominates in skin blood vessels and ligaments. It is a unique interstitial collagen, analogous to types I, II, V, and XI. It has a specific role in the strength and stability of blood vessels where it exerts its maximum clinical effect. The protein is a homotrimer $[\alpha 1(\mathrm{III})]_{3}$ with two intrachain cysteine cross links at the $\mathrm{C}$ terminus. Collagen III deficiency, in the main, causes vascular EDS but may also cause other less specific phenotypes such as EDS III.

Two patterns are usual. The first (group 1) exhibits poorly secreted and overhydroxylated collagen III proteins caused by either helical glycine substitutions or exon skips. The stoichiometry dictates that only one-eighth of the triple helices are normal. The remaining seven-eighths contain either one, two, or three faulty $\alpha 1$ (III) chains which are consequently retained intracellularly or poorly secreted and degraded. Not surprisingly, patients with such severe biochemical deficiencies have severely abnormal clinical phenotypes. The second abnormal pattern includes null alleles (group 2 ). Here reduced collagen type III secretion 

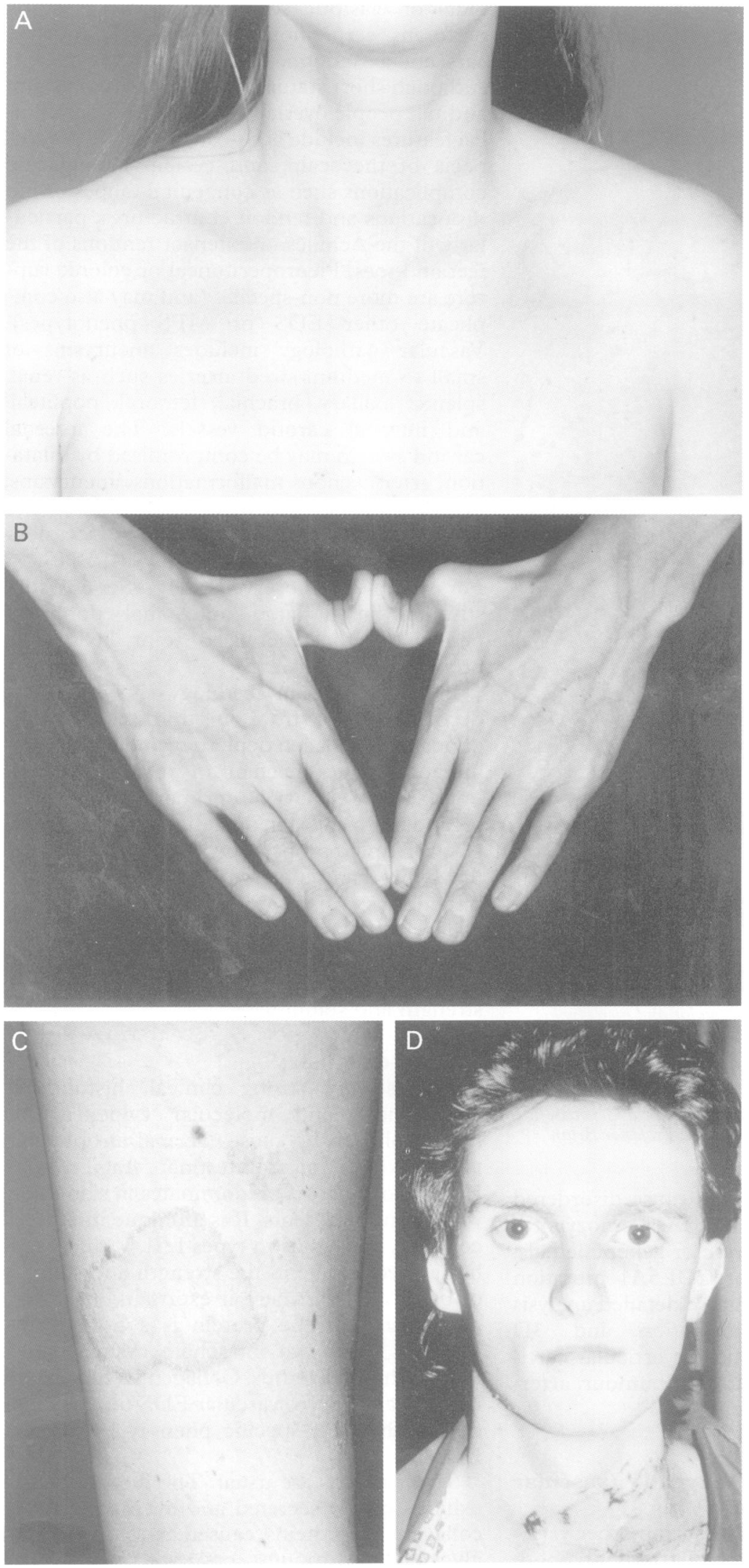

Figure 3 Various clinical features of vascular EDS IV (COL3A1 mutations). Thin skin $(A)$, prematurely aged hands $(B)$, and facial features typify the acrogeric subtype $(D)$. Sometimes there is a characteristic circinate rash (elastosis perforans serpiginosa) although this can occasionally complicate other inherited connective tissue disorders $(C)$.

without intracellular retention or overmodification is the norm. The other allele is usually wild type but occasionally can be mutant. In contrast to the secretory (group I) mutants, collagen III, although poorly secreted, is not overmodified. In other words the residual collagen III molecules are usually normal. Thus, the clinical phenotype is milder, more difficult to diagnose, and overlaps with EDS III/BHS or even merges into normality. Similarly, the arterial phenotype varies; occasionally there is premature aortic rupture, internal carotid or cerebral arterial dilatation, or arterial rupture. In contrast, the more spectacular carotid-cavernous-sinus aneurysms segregate with group I mutations. The group 2 (null allele) phenotype of arterial dilatation and cutaneous striae also overlaps clinically with atypical forms of MFS, from which it may be clinically indistinguishable.

\section{Molecular pathology of COL3A1 mutants (fig 4)}

Since 1991, there have been rapid advances in phenotype/genotype correlations. Generally, 3' mutations are acrogeric whereas the phenotypes of $5^{\prime}$ or middle helical exon skips are harder to recognise. Unfortunately, even the latter are at risk of arterial rupture which is nevertheless much more frequent in mutations at the 3' end. Arterial rupture is difficult, if not impossible, to predict, occurring as early as the second decade (rare) to early or late middle age (very common). Like analogous COL1A1, $1 \mathrm{~A} 2$, or $2 \mathrm{~A} 1$ mutations, ${ }^{750-55}$ they are virtually private to affected families. They include autosomal dominant glycine substitutions or exon skips. So far, only three large in frame deletions ranging from 0.5 to $3 \mathrm{~kb}$ have been reported. ${ }^{53-55} \mathrm{~A}$ smaller $27 \mathrm{bp}$ intraexonic deletion was caused by spliced mispairing. ${ }^{56}$ All disrupt the collagen triple helix by a dominant negative mechanism. Here, each trimer is either wild type, or contains three, two, or one abnormal chains in homotrimers such as collagens II and III or in heterotrimers such as collagen I. Thus, COL3A1 mutations cause severe disturbance with seven-eighths of the protein molecules abnormal compared to heterotrimers such as type I collagen where between half and three-quarters are faulty, ${ }^{50}$ depending whether the mutation affects COL1A1 or COL1A2. Both homozygosity and heterozygosity for various COL3A1 mutations or compound heterozygosity with other collagen or extracellular matrix molecules are also theoretically possible, although to date there have been no published examples. Similar considerations also apply to COL1A1 and COL1A2 (OI mutants) in which only occasional double mutations have been identified. Perhaps such double hits would be catastrophic in widespread tissue components such as collagen I or III. In contrast, double mutations of minority components like collagen VII are relatively common. Thus, double glycine substitutions cause severe recessive dystrophic epidermolysis bullosa while in contrast single glycines are either clinically silent or can cause minor autosomal dominant epidermolysis bullosa. ${ }^{57}$

Reliable genetic counselling and prenatal diagnosis are available for most vascular EDS patients. This requires a combination of histology, electron microscopy, and type III collagen 
A

COL3A1 point mutations
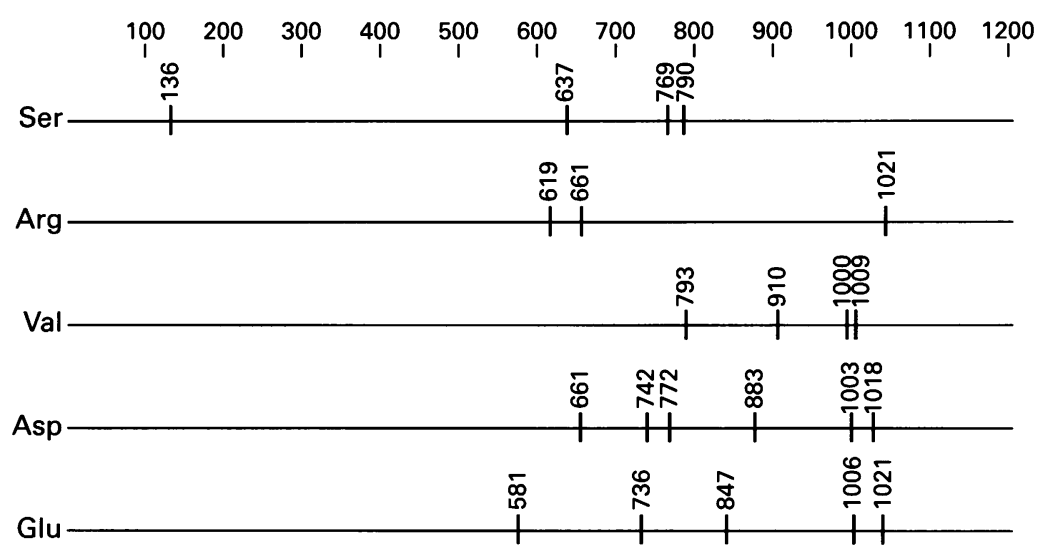

B

COL3A1 splicing and deletions
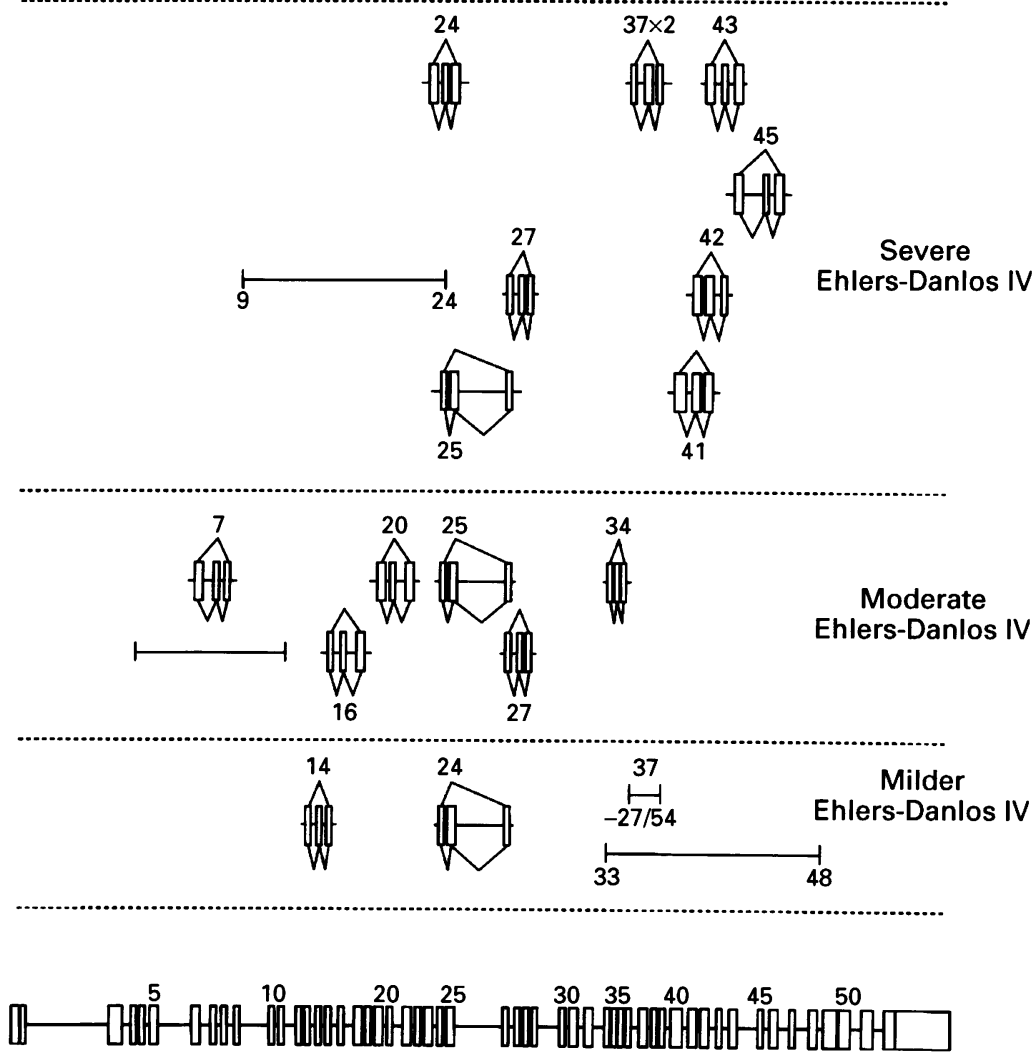

Figure 4 Map of recently published COL3A1 mutations. (A) Glycine substitutions arranged by residue number and $(B)$ exon skips or large deletions (studies of Kuivaniemi et al ${ }^{60}$ and Pope et $a l^{48}$. diagramatically in fig 4 . Other mutants are referred to in other studies. ${ }^{60-64}$ Opinions differ as to the relevance of collagen III mutations in intracranial and aortic aneurysms. ${ }^{486567}$ There is little doubt that COL3A1 mutations do cause such defects but how frequently remains to be determined.

\section{Collagen type I mutations (fig 5)}

Collagen type $I$ is a heterotrimer ([ $\left.\alpha 1(\mathrm{I})]_{2} \alpha 2(\mathrm{I})\right)$ of two different $\alpha$ chains. The genes COL1A1 and COL1A2 are located on chromosomes 17 and 7 respectively. Both are interstitial collagens with uninterrupted (GlyXY) triple helices and globular, removable $\mathrm{N}$ and $\mathrm{C}$ termini; other fibrillar collagens include types II, III, V, and XI, all with cross banded fibrils. Mutations of COL1Al and COL1A2 produce distinctive but overlapping clinical phenotypes which are position, type, and domain related. ${ }^{50-52}$ Mutations of either $\mathrm{N}$ terminal extensions each cause EDS VII (with distinctive clinical features) while, in contrast, helical and $\mathrm{C}$ terminal mutations cause OI. As expected, OI and EDS VII overlap clinically and biochemically. ${ }^{68}{ }^{69}$ In EDS VII, cutaneous fragility and ligamentous laxity predominate, while in OI the bones are abnormally fragile. OI families with loose ligaments and fragile, delicate blood vessels and skin are uncommon, while otherwise typical EDS families sometimes have bone fragility/osteoporosis. The clinical phenotype is strictly dictated by mutational position and EDS VII is an especially focused example. Its mutations all cause skipping of exon 6 of either the COLlAl or COL1A2 gene. ${ }^{27} 5051$ By contrast, mutations which cause OI are more diffusely distributed between exons 7 and 52 . In general the phenotype worsens with higher exon numbers ( 3 ' end or C terminal locations). EDS VII is caused by two distinct but related mechanisms. Either there is a structural abnormality of the peptidase cleavage site or the cleaving enzyme is faulty.

\section{EDS type VII (fig 6E)}

There are two distinctive clinical phenotypes, one overlapping with EDS I/II and the other with congenital cutis laxa. The former is mild and autosomal dominant, while the latter is severe and autosomal recessive. EDS VIIA and $B$ result from structural mutations of type I collagen, ${ }^{22}$ while EDS VIIC is caused by the enzyme deficiency. Clinical signs include short stature and excessive premature ligamentous laxity (such as congenital dislocation of the hips). There may also be excessive cutaneous fragility reminiscent of EDS I/II, or mild cutis laxa (CL). Spinal and ligamentous deformities such as kyphoscoliosis are relatively infrequent. In contrast to EDS I/II, in EDS VIIA and B collagen fibril morphology is only marginally abnormal and the fibres are angular in transverse section rather than forming cauliflowers (fig 2A, B). On the other hand, EDS VIIC shows grossly distorted, hieroglyphic fibrils. 
Normal allele

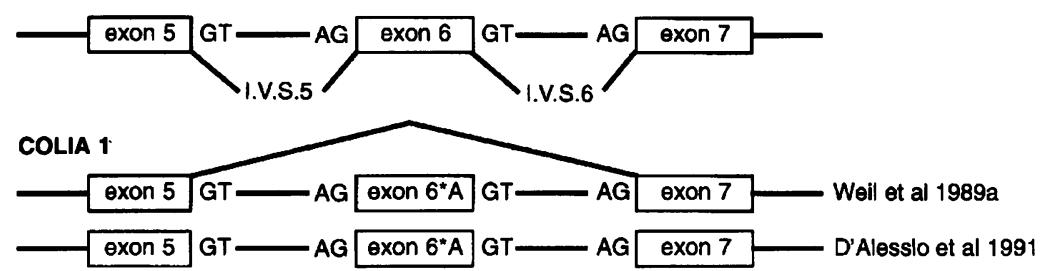

COLIA 2

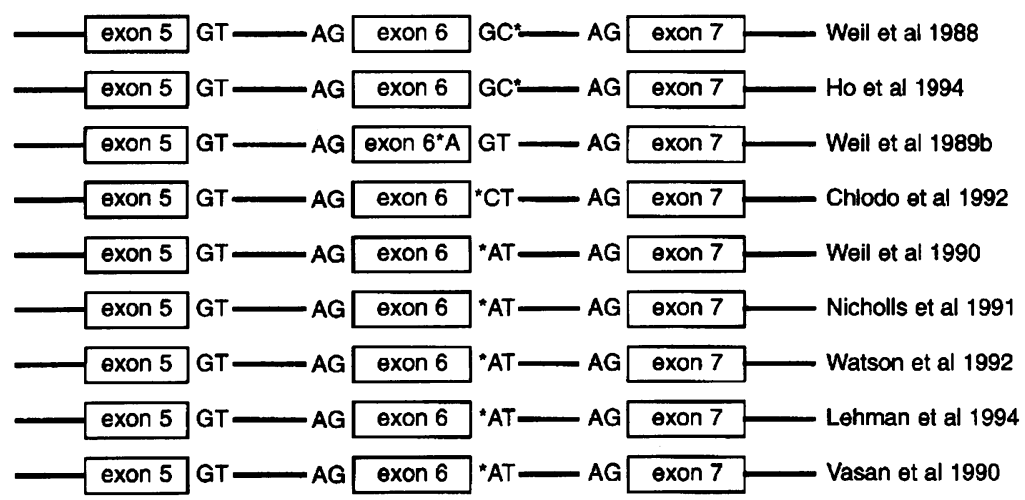

Figure 5 Diagrammatical representation of various published exon 6 splice junction mutations causing EDS VII A or B. Coding sequences (exons) are boxed while non-coding sequences (introns) are shown as lines. The first two bases (splice donor) and last two bases (splice acceptor) of the intron sequence are always $G T$ or $A G$ respectively. Mutations are denoted by asterisks.

\section{Deletion of the peptidase cleavage site}

Since collagen type $I$ is a heterotrimer, loss of either the $\mathrm{pN} \alpha 1$ or $\mathrm{pN} \alpha 2$ cleavage sites can cause EDS VII. When $\mathrm{pN \alpha} 1$ sequences are uncleaved three-quarters of collagen type I heterotrimers possess either one or two persistent $\mathrm{pN} \alpha$ chains. With $\mathrm{pN} \alpha 2$ defects, half the type I collagen retains abnormal $\mathrm{pN} \alpha 2$ sequences while the rest become normal $\alpha 2$ chains. In both circumstances collagen fibril assembly is compromised and normal head to tail packing of individual triple helical molecules is severely disrupted. The persistent $\mathrm{pN}$ sequences seriously distort gap regions. Such misassembled fibrils are visible by transmission electron microscopy, which shows slightly irregular to angulated structures in cross section. When thicker than $10 \mathrm{~nm}$, both initial nucleation and subsequent fibril growth are seriously distorted by the presence of persistent $\mathrm{pN} \alpha$ sequences ${ }^{37-41}{ }^{71}$ which are longer than the aggregating $\alpha$ chains. Exon skips also disrupt type I collagen $\alpha$ chains since both the pepsin and peptidase cleavage sites are deleted. Protein electrophoresis of pepsinised $\alpha$ chains therefore shows elongated molecules with abnormally persistent $\mathrm{pN}$ sequences in addition to the correctly cleaved normal $\alpha$ chains. Such abnormal pN proteins can also be purified from $\mathrm{NaCl}$ extracted tissues. Procollagen "snapshots" also show inefficient processing patterns. Following the original descriptions of Lichtenstein $e t a l^{22}$ of faulty conversion of procollagen to collagen in EDS VII, persistent $\mathrm{pN} \alpha 1$ and $\mathrm{pN} \alpha 2$ components were separately demonstrated by Steinmann et $a l^{071}$ and Cole et al. ${ }^{72}{ }^{73}$ Subsequently, various missplicing mutations of exon 6 sequences caused by faulty splice acceptor or donor sequences have been discovered. Most are near to the obligate
G of the $5^{\prime}$ intron acceptor GT sequence in intron 6 (fig 5). ${ }^{74-84}$

Mutations of procollagen peptidase (PP) PP deficiency of cows was first described by Lapière et al. ${ }^{85}$ The animals had excessively fragile skin (dermatosparaxis), which was a genetic lethal. Transmission EM of the dermis showed numerous bizarrely shaped collagen fibrils which formed flanged rods instead of normal cylinders. In transverse section these appeared as hieroglyphs while in longitudinal section they were severely disaggregated and twisted. Biochemical analysis showed abnormally elongated collagen $\mathrm{pN} \alpha 1$ and $\alpha 2$ chains which were extractable with salt or acid solutions, implying abnormal cross linking. At the time, procollagen was thought to have single $\mathrm{N}$ terminal extensions and no $\mathrm{C}$ terminal additions. In contrast to EDS type VIIA and B (see above), every component of type I triple helix are abnormal, that is, contains both $\mathrm{pN} \alpha 1$ (1) and $\mathrm{pN} \alpha 2$ (1) chains. Consequently, no normal collagen triple helices are formed: instead fibrils assembled form $[\mathrm{pN} \alpha(\mathrm{I})]_{2}$ $\mathrm{pN} \alpha 2$ (I) triple helices. Consequently, fibrillar packing is very seriously disrupted (fig $2 \mathrm{C}$ ). The equivalent human phenotype was not identified until recently. ${ }^{85-89}$ Various other animal models such as sheep ${ }^{90}$ and Himalayan cats ${ }^{91}$ were described previously, but included very convincing clinical and structural data, and the expected hieroglyphic fibrils and deranged biochemistry. The human clinical phenotype unexpectedly showed premature cutis laxa (CL) with blepharochalasis. So far three examples have been published, two with exceptionally clear biochemical data and the third with excellent illustrations of the clinical phenotype. ${ }^{87-89}$ Both the French and American descriptions included disturbed procollagen processing, $\mathrm{pN} \alpha 1$ (1) or $\alpha 2$ (1) molecules, hieroglyphic fibres, and deficient enzyme levels. The phenotype of Smith et a ${ }^{8}$ included premature delivery, soft, fragile, and easily bruised skin, and patchily sagging skin, while in the patient of Nusgens $e t a l,{ }^{87}$ skin fragility, bruising, and generalised osteoporosis were notable. Reardon et $a l,{ }^{89}$ in contrast, described severe premature generalised CL with blepharochalasis, redundant skin, and fragility. Every patient had typical hieroglyphic fibrils. Transient CL also occurs with the milder EDS VII type A and B phenotypes in which skin fragility varies. Even though less disrupted than dermatosparaxis, the fibrils of EDS VII A and B can be manipulated to produce hieroglyphics under suitable experimental conditions. ${ }^{92}$ Plainly the faulty angular fibrils characteristic of exon 6 deletions (which cause EDS VII A and B) are one step in the progression from normal cylinders to hieroglyphs. Theoretically both more localised and extensive mutations within and around exon 6 of the $\mathrm{N}$ propeptide coding region could produce a wider spectrum of fibrillar angularity and clinical features which are maximised in the propeptidase enzyme deficiency of animals and humans. 

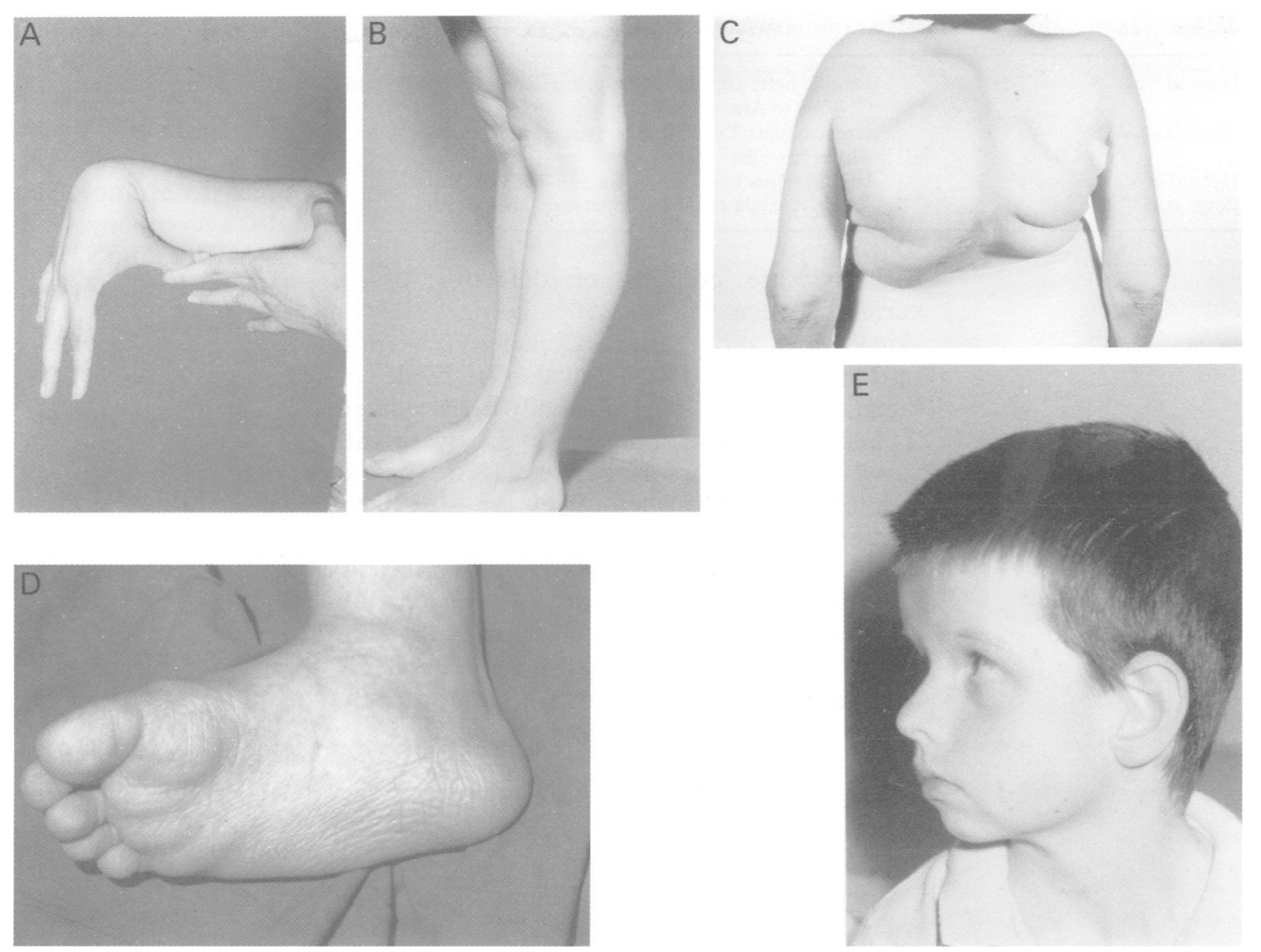

Figure 6 Various physical features of $E D S$ III $(A, B), E D S$ VI $(C, D)$, and EDS VII $(E)$. In practice a degree of laxity $(A, B)$ can complicate any of the EDS subtypes but is a sole feature in EDS III. Scoliosis is a consistent feature of EDS VI, sometimes complicates EDS VII, and rarely occurs in EDS I, II, and III. The criss cross lines shown in (D) are typical of either EDS VI or EDS VII and a slight facial cutis laxa is particularly characteristic of EDS VII (E). At other times the

latter shows cutaneous fragility very similar to that of fig 1 .

\section{Other enzyme abnormalities causing EDS}

Other crucial post-translational modifications of fibrillar collagen triple helices include enzymatic hydroxylation of certain lysines and excision of the $\mathrm{C}$ propeptides in addition to trimming by the specific $\mathrm{N}$ propeptidases. Lysyl oxidase then promotes cross links by decondensing hydroxylysines to aldehydes. Mutated enzymes cause very specific forms of EDS. Thus, lysyl hydroxylase (LH) deficiency causes EDS VIA ${ }^{93-104}$ while procollagen peptidase deficiency causes EDS VIIC ${ }^{85-87}$ (see also above). The role of lysyl oxidase is more controversial $^{105106}$ and so far the diseases caused by $\mathrm{C}$ terminal propeptidase mutations are unknown. Since the $C$ propeptide is essential for chain association, homozygous enzyme mutations might be genetically lethal. Bone morphogenic protein 1 (BMP1) and the C propeptidase are now known to be identical. ${ }^{107} 108$

\section{Ehlers-Danlos syndrome type VI (lysyl hydroxylase deficiency) (fig 6C)}

The disorder was first recognised as unique by McKusick, ${ }^{12}$ although Beighton et $a l^{13}$ had observed autosomal recessive inheritance in a family with severe spinal deformities, ligamentous laxity, ocular fragility, and retinal detachment. There is extreme ligamentous laxity with severe ocular fragility, retinal detachment, and scleromalacia. The severe ligamentous problems present in early infancy usually with motor delay caused by severe muscular hypoto- nia. Sometimes muscular dystrophy is (wrongly) suspected but nearly all affected children eventually walk normally. The difficulties are caused by excessive ligamentous laxity which young muscles cannot adequately control. In adult life or middle age, there may be aortic dilatation or arterial rupture.

Krane et $a l^{33}$ and Pinnell et $a l^{94}$ then discovered underhydroxylation of lysine and deficient collagen lysyl hydroxylase in two affected sisters with severe infantile hypotonia, premature scoliosis, and ocular fragility. Other significant features included soft, hyperextensible, easily scarred skin and premature rupture of the membranes. There are two similar clinical phenotypes, type VIA with enzyme deficiency and type VIB with normal enzyme. There may also be a third, predominantly ocular, variant.

\section{Biochemistry and molecular pathology (table 2)}

Krane et $a l^{93}$ and Pinnell et $a l^{94}$ measured enzyme activity using tritium labelled chick procollagen as substrate. Nearly 20 years later, both the chick and human genes were cloned and sequenced. ${ }^{95}{ }^{96} \mathrm{LH}$ or procollagen lysyl 2 oxoglutarate 5 dioxygenase requires copper, $\mathrm{Fe}^{++}$, and $\mathrm{O}_{2}$ as cofactors. EDS VI is caused by either deficient or faulty enzymes with variable $\mathrm{Km}$ or $\mathrm{V}$ max..$^{97}{ }^{98}$ The mutations are often complex and include Alu-Alu compound recombinations and homozygous or double heterozygous exon skips. ${ }^{98-102}$ Homozygous deletions tend to cluster in inbred families. The 
Table 2 Lysyl hydroxylase mutations (the gene has 19 exons)

\begin{tabular}{ll}
\hline Ha et al ${ }^{98}$ & $\begin{array}{l}\text { Double heterozygote } 3 \text { base pair deletion Glu (-) } 532 \text { and } \\
\text { Gly } 678 \text { to Arg }\end{array}$ \\
Hautala et al & Homozygous 7 exon duplication rearrangement at Alu/ \\
& Alu in two sibs \\
Hyland et al al $^{100}$ & Homozygous stop codon Arg 319-X:CGA-TGA \\
Pousi et al & As for Hautala et al ${ }^{99}$ but in an unrelated female
\end{tabular}

hydroxylysine content of defective tissues varies between $5 \%$ and $50 \%$ being lowest in skin, bone, and tendon. Collagen $I$ is more underhydroxylated than collagen III, while collagens II, IV, and V are normally hydroxylated. This implies more than one hydroxylase with variable specificity for other collagen types, so that other clinical phenotypes are also likely. Underhydroxylation of collagen $\alpha 1(1)$ and $\alpha 2(1)$ chains causes overmigration and impairs condensation cross linking of adjacent hydroxylysines which can be measured in urine. ${ }^{103}{ }^{104}$ Urine sampling and type I collagen $\alpha$ chain electrophoresis are simple and useful screens for enzyme deficiency.

\section{The C terminal propeptide (BMP1) deficiency}

It is now apparent that the $C$ terminal propeptidase (CPP) is identical to bone morphogenetic protein 1 (BMP1). The latter is homologous to the Drosophila pattern formation genes TLD and TRI with analogues in insects and sea urchins, such as the BP 10 and SpAN genes which are TGF $\beta$ activators. ${ }^{107}$ Homozygous enzyme deficiencies would either be genetic lethals or severely crippling in mechanical terms. Persistence of $\mathrm{pC}$ extensions would severely impair collagen triple formation just as persistent $\mathrm{pN}$ sequences interfere with molecular packing. Errors of the pC extensions would seriously disrupt both helical winding and chain association; quite possibly collagen triple helices would not form at all. The effects of $C$ propeptidase deficiency should be worse than $\mathrm{N}$ propeptidase deficiency which causes EDS VIIA-C. Holmes et $a l^{2}$ studied the stepwise removal of $\mathrm{pC}$ or $\mathrm{pN}$ propeptides before collagen fibrillogenesis. Retention of either extension by faulty processing inhibits fibril formation as do helical mutations of the fully processed molecule.

Heterozygotes for CPP deficiency might also have impaired fibrillogenesis. Homozygosity could easily cause severe clinical phenotypes, such as lethal OI, and certain severe chondrodysplasias or EDS variants either as allelic homozygotes or as double heterozygotes in combination with other ECM propeptide mutations such as pC I, II, III, V, or XI abnormalities respectively.

\section{EDS variants of unknown cause}

This applies to EDS types III, VIII, and X in which the causes are non-specific (EDS III), variable (EDS VIII), or represented by a single one-off example (EDS VIII).

\section{EDS type III (fig 6 A, B)}

Unlike EDS types I and II there is no significant cutaneous scarring despite obvious joint hypermobility and doughy skin. This clinical subtype merges with the so-called benign hypermobile syndrome (BHS) but which has normal skin texture. This milder clinical phenotype can also segregate in typical EDS I/II families probably owing to incomplete penetrance. Similar clinical features may also accompany COL $3 \mathrm{~A} 1$ mutations, ${ }^{48-50}$ such as MFS and SS. Heterozygotes for autosomal recessive disorders such as PXE and lysyl hydroxylase deficiency (EDS VI) have very similar clinical phenotypes. ${ }^{109}$ There can also be overlap (clinical and biochemical) with vascular EDS (see above).

\section{EDS type VIII}

First described by Stewart et al ${ }^{110}$ this phenotype is clinically, biochemically, and allelically heterogeneous. Distinguishing clinical features include chronically inflamed, heavily pigmented, discrete, pretibial plaques and premature periodontal recession. There is collagen degradation as judged by gum resorption and the cutaneous inflammation. In EDS VIII no consistent biochemical or structural changes are detectable..$^{110-114}$ Certain mutant collagens may be abnormally proteinase susceptible. Alternatively, faulty collagenase inhibitors such as TIMP might be implicated, although all of our EDS VIII patients have normal TIMP profiles. We have observed both vertical and horizontal transmission of early adult gum recession, sometimes accompanied by collagen III deficiency. Similar features may accompany EDS I, II, and IV. Others have also noted this phenotype. ${ }^{111-114}$ The distinctive clinical phenotype $^{106}$ is therefore biochemically and genetically heterogeneous. Histology of the skin lesions shows a granulomatous collagen degeneration resembling necrobiosis lipoidica. ${ }^{115}$

Ehlers-Danlos syndrome with fibronectin deficiency (EDS X)

Only one family with this phenotype has been described. ${ }^{116}$ This included four affected sibs in one generation but with normal parents, which McKusick later classified as autosomal recessive. The phenotype includes thin, fragile, easily scarred skin, joint hypermobility, and excessive bruising and therefore resembles EDS II/III. Platelet aggregation was abnormal but correctable with normal fibronectin. In other EDS families a variety of clotting abnormalities have been described which are too inconsistent to be directly related. ${ }^{117} 118$

1 Tschernogobow A. Cutis laxa (presentation at the First Meeting of the Moscow Dermatological and Venereologic Seciety, November 13, 1891). Mscht Prakt Derm 1892;14:76.

2 Ehlers E Cutis Laxa neigung zu haemorrhagien in der haut, lockerung mehrerer artikulationen. Dermatologische lockerung mehrerer

3 Danlos M. Un cas de cutis laxis avec tumeures par Danlos $M$. Un cas de cutis laxis avec tum (xanthome contusion chronique des coudes MM Hallopeau et Mace de juvenile pseudo-diabetique) de MM Hallopeau et

Lepinay. Bull Soc Franc Derm Syph 4 Poumeau-Delille GA, Soulie $\mathrm{P}$. Un cas d'hyperlaxite
cutanee et articulaire avec cicatrices atrophiques et cutanee et articulaire avec cicatrices atrophiques et pseudo-tumeurs molluscoides (syndrome d'Ehlers-
Danlos). Bull Soc Med Hopitaux de Paris 1934;50:593-5.

5 Beighton P. Ehlers-Danlos syndrome. London: Heinemann Medical Books, 1970.

6 Morris M. Diseases of the skin. 4th ed. Plate XL. London: Cassell \& Co, 1908 
7 Beighton P. McKusick's heritable disorders of connective tissue. 5th ed. St Louis: Mosby, 1993.

8 Mories A. Ehlers-Danlos syndrome, with the report of a fatal case. Scot Med F 1960;5:269-72.

9 Barabas AP. Heterogeneity of the Ehlers-Danlos syndrome: description of three clinical types and a hypothesis to description of three clinical types and a hyp
explain the basic $\operatorname{defect}(\mathrm{s})$. BMf 1967;ii:612-13.

10 Beighton P. Lethal complications of the Ehlers-Danlos syndrome. $B M \mathcal{F}$ 1968;ii:656-60.

11 Beighton P. X-linked recessive inheritance in the EhlersDanlos syndrome. $B M \mathcal{A}$ 1968;ii:409-11.

12 McKusick VA. Ehlers-Danlos syndrome. In: Heritable disorders of connective tissue. 4th ed. St Louis: Mosby, 1972:292371 .

13 Beighton P, De Paepe A, Danks D, et al. International nosology of heritable disorders of connective tissue, Berlin 1986. Am ₹ Med Genet 1988;29:581-4.

14 Beighton P, De Paepe A, Hall JG, et al. Molecular nosology of heritable disorders of connective tissue. Am $\mathcal{F}$ Med Genet of heritable disorder.

15 Kopp J. Demonstration zweier Fälle im "Cutis Laxis." Munchen Med Wochenshrift 1888;135:259.

16 Wiener K. Gummihaut (Cutix Laxa) mit diminanter vererbung. Arch Dermatol Syph 1924;148:559-61.

17 Stuart AM. Three cases exhibiting the Ehlers-Danlos syndrome. Proc $R$ Soc Med Lond 1937;30:984-6.

18 Coe M, Silver SH. Ehlers-Danlos syndrome (cutis hyperelastica). Am f Dis Child 1940;59:129-35.

19 Johnson SAM, Falls HF. Ehlers-Danlos syndrome: a clinical and genetic study. Arch Dermatol Syph 1949;60:82-105.

20 Weber FP, Aitken J. Nature of the subcutaneous spherules in some cases of Ehlers-Danlos syndrome. Lancet 1938;i:198 200.

21 Ronchese F. Dermatorrhexis with dermatochalasis and arthrochalasis (the so called Ehlers-Danlos syndrome). $\mathrm{Am}$ f Dis Child 1936;5:1403-10.

22 Lichenstein JR, Martin GR, Kohn LD, et al. Defect in conversion of procollagen to collagen in a form of EhlersDanlos syndrome. Science 1973;182:292-300.

23 Pope FM, Martin GR, Lichtenstein JR, et al. Patients with Ehlers-Danlos syndrome type IV lack type III collagen. Proc Natl Acad Sci USA 1975;72:1314-16.

24 Pope FM, Martin GR, McKusick VA. Inheritance of Pope FM, Martin GR, McKusick VA. Inheritance of
Ehlers-Danlos syndrome type IV syndrome. Arch Dis Child 1977;63:1016-25.

25 Suhl HMB, Steinmann B, Rao VH, et al. Ehlers-Danlos syndrome type IVD: an autosomal recessive disorder. Clin Genet 1984;25:278-87.

26 Beasley R, Cohen MM Jr. A new presumably autosomal recessive form of Ehlers Danlos syndrome. Clin Genet 1979;16:19-24.

27 Pope FM. Ehlers-Danlos syndrome. Rheumatic manifestations of haematological disease. Ballieres Clin Rheumatol tions of haema

28 Nicholls AC, McCarron S, Narcisi P, et al. Molecular abnormalities of type $\mathrm{V}$ collagen in Ehlers-Danlos synabnormalities of type V collagen in Eht

29 Nicholls AC, Oliver JE, McCarron S, et al. An exon skipping mutation of a type $\mathrm{V}$ collagen gene (COL5AI) in Ehlers-Danlos syndrome. $\mathcal{F}$ Med Genet 1996;33:940-6.

30 Andrikopoulos K, Liu X, Keene DR, et al. Targeted mutation in the col5a2 gene reveals a regulatory role for type $\mathrm{V}$ collagen gene during matrix assembly. Nat Genet 1995;9:31-6.

31 Loughlin J, Irwen C, Butcher S, et al. Linkage of the gene that encodes the $\alpha \mathrm{I}$ chain of type V collagen (COL5AI) to type II Ehlers-Danlos syndrome (EDS II). Hum Mol Genet type II Ehlers-Danto

32 Burrows NP, Nicholls AC, Yates JRW, et al. The gene encoding collagen $\alpha 1(V)$ (COL5A1) is linked to mixed 106:1273-6.

33 Toriello HV, Glover TW, Takahara K, et al. A translocation interrupts the COL5Al gene in a patient with EhlersDanlos syndrome and hypomelanosis of Ito. Nat Genet 1996;13:361-5.

34 Wenstrup RJ, Langland G, Willing MC, et al. A splicejunction mutation in the region of COL5A1 that codes for the carboxyl propeptide of pro- $\alpha 1(\mathrm{~V})$ chains results in the gravis form of the Ehlers-Danlos syndrome (type 1). Hum Mol Genet 1996;5:1733-6.

35 De Paepe A, Nuytinck L, Naeyart JM. Substitution of a highly conserved cysteine in the C-propeptide of the pro highly conserved cysteine in the C-propeptide of the pro
$\alpha 21$ (V) collagen chain causes Ehlers-Danlos syndrome a21(V) collagen chain causes Ehlers-
type I. Am f Hum Genet 1996;59:A255.

36 Greenspan DS, Northrup H, McAllister KA, et al. COL5A1: fine genetic mapping and exclusion as candidate gene in families with nail-patella syndrome, tuberous sclerosis, hereditary haemorrhagic telangiectasia and EhlersDanlos syndrome type II. Genomics 1995;25:737-9.

37 Birk DE, Fitch JM, Babiarz JP, et al. Collagen fibrillogenesis in vitro: interaction of types $I$ and $V$ collagen regulates fibril diameter. F Cell Sci 1990;95:649-57.

38 Birk DE, Fitch JM, Babiarz JP, et al. Collagen I and V are present in the same fibril in the avian corneal stroma. $f$ Cell Biol 1988;106:999-1008.

39 Linsenmayer TF, Gibney E, Igoe F, et al. Type V collagen: molecular structure and fibrillar organisation of chicken al(V) $\mathrm{NH}_{2}$-terminal domain, a putative regulator of corneal fibrillogenesis. $\mathcal{F}$ Cell Biol 1993;121:1181-9.

40 Moradi-Ameli M, Rousseau JC, Klemen JP, et al. Diversity in the processing events at the $\mathrm{N}$ terminus of collagen $\mathrm{V}$. Eur $\mathcal{f}$ Biochem 1994;221:987-95.
41 Broek DL, Madri J, Eikenberry EF, et al. Characterisation of the tissue form of type $\mathrm{V}$ collagen from chick bone. $\mathcal{F}$ Bio Chem, 1985;260:555-62.

42 Vikkula M, Mariman ECM, Liu VCH, et al. Autosomal dominant and recessive osteochondrodysplasias associated with the COL11A2 locus. Cell 1995;80:431-7.

43 Richards AJ, Yates JR, Williams R, et al. Stickler syndrome type 2 has a mutation in the COL11A1 gene resulting in the substitution of glycine 97 by valine in $\alpha 1$ (XI) collagen. Hum Mol Genet 1996;5:1339-43.

$44 \mathrm{Li} \mathrm{Y,} \mathrm{Laurda} \mathrm{DA,} \mathrm{Warman} \mathrm{ML,} \mathrm{et} \mathrm{al.} \mathrm{A} \mathrm{fibrillar} \mathrm{collagen}$ gene, Col $11 \mathrm{a} 1$ is essential for skeletal morphogenesis. Cell 1995;80:423-30.

45 Mayne R, Brenton RG, Mayne PM, et al. Isolation and characteristics of the chains of type V/type XI collagen present in bovine vitreous. F Biol Chem 1993;268:9381-6.

46 Hausser I, Anton-Lamprecht I. Differential ultrastructural alterations of collagen fibrils in Ehlers-Danlos syndrome types I-IV as a means of diagnosis and classification. Hum Genet 1994;3:394-407.

47 Sack G. Status dysvascularis: Ein falle von besonderer Zerreislichkeit de Blutgefasse. Deutsch Arch Klin Med 1936;178:663-9.

48 Pope FM, Narcisi P, Nicholls AC, et al. COL3A1 mutations cause variable clinical phenotypes including acrogeria and vascular rupture. $\mathrm{Br}$ f Dermatol 1996;135:231-6.

49 Narcisi P, Richards AJ, Ferguson SD, et al. A family with Ehlers-Danlos syndrome type III/articular hypermobility syndrome has a glycine 637 to serine in type III collagen. Hum Mol Genet 1994;3:1617-20.

50 Pope FM. Molecular abnormalities of collagen. In: Maddison PJ, Isenberg DA, Woo P, Glass D, eds. Oxford textbook of rheumatology. Vol I. Chapter 2.2. Oxford: Oxford Univerof rheumatology.

51 Prockop DJ, Kivirrikko KI. Collagens: molecular biology diseases and potentials for therapy. Annu Rev Biochem 1995;64:403-34

52 Cole WG, Dalgleish R. Perinatal lethal osteogenesis imperfecta. F Med Genet 1990;32:286-9.

53 Lee B, D'Alessio M, Vissing H, et al. Characteristics of a large deletion associated with a polymorphic block of reported dinucleotides in the type III procollagen gene (COL3A1) in a patient with Ehlers Danlos syndrome type IV. Am F Hum Genet 1991;48:511-17.

54 Vissing H, D'Alessio M, Lee B, et al. Multi exon deletion in the procollagen III gene is associated with mild EDS type IV. $\mathcal{F}$ Biol Chem 1991;266:5644-8.

55 Milewicz DM, Witz AM, Smith AC, et al. Parental somatic and germline mosaicism for a multi exon deletion with unusual end points in a type III collagen which produces Ehlers-Danlos syndrome type IV in the heterozygote offspring. Am 7 Hum Genet 1993;53:62-70.

56 Richards AJ, Lloyd JC, Narcisi P, et al A 27 base-pair deletion from one allele of the type III collagen gene (COL3A1) in a large family with a typical Ehlers-Danlos syndrome type IV. Hum Genet 1992; 88:325-30.

57 Christiano AM, Anton-Lamprecht I, Amano S, et al. Compound heterozygosity for COL7A1 mutations in twins with dystrophic epidermolysis bullosa; a recessive paternal deletion/insertion mutation and dominant negative maternal glycine substitution results in a severe phenotype. $A m \mathcal{F}$ Hum Genet 1996;58:682-93.

58 Rudd NL, Nimrod C, Holbrook KA, et al. Pregnancy complications in type IV Ehlers Danlos syndrome. Lancet 1983;i:50-3.

59 Pope FM, Nicholls AC. Pregnancy and Ehlers-Danlos syndrome type IV. Lancet 1983;i:249-50.

60 Kuivaniemi H, Tromp G, Bergfeld WF, et al. Ehlers-Danlos syndrome type IV: a single base substitution of the last syndrome type IV: a single base substitution of the last
nucleotide of exon 34 in COL 3A1 leads to exon skipping. $f$ nucleotide of exon 34 in COL 3A

61 Richards AJ, Narcisi P, Ferguson C, et al. Two new mutations affecting the donor splice site of COL3A1 IVS 37 are causing skipping of exon 37 in patients with EhlersDanlos syndrome type IV. Hum Mol Genet 1994;3:1901-2.

62 Lloyd J, Narcisi P, Richards A, et al. T+6 to C+6 mutation in the donor splice of COL3A1 IVS7 causes exon skipping and results in Ehlers-Danlos syndrome type IV. $\mathcal{F} \mathrm{Med}$ Genet 1993;30:376-80.

63 Richards AI, Narcisi P, Lloyd J, et al. The substitution of glycine 661 by arginine in type III collagen produces mutant molecules with different thermal stabilities and causes Ehlers-Danlos syndrome type IV. $₹$ Med Genet causes Ehlers-

64 Nuytinck L, De Paepe A, Pierard GE, et al. Single strand conformation polymorphism (SSCP). Analysis of the COL $3 A 1$ gene detects a mutation that results in the substitution of glycine 1009 valine and causes severe EhlersDanlos syndrome type IV. Hum Mutat 1994;3:268-74.

65 Tromp G, Wu Y, Prockop DJ, et al. Sequencing of cDNA from 50 unrelated patients reveals that mutations in the triple-helical domain of type III procollagen are an infrequent cause of aortic aneurysms. $f$ Clin Invest 1993;91:2539-45.

66 Kuivaniemi H, Prockop DJ, Wu Y, et al. Exclusion of mutations in the gene for type III collagen (COL3A1) as a common cause of intror mon cause of intracranial aneurysms or cervical artery dissections: results from sequence analysis of the coding
sequence of type III collagen from 55 unrelated patients. Neurology 1993;43:2652-8.

67 Pope FM, Kendall BE, Slapak GI, et al. Type III collagen mutations cause fragile cerebral arteries. Br $\mathcal{F}$ Neurosurg
$1991 ; 5: 537-57$. 
68 Hata R, Kurata SI, Shinkai H. Existence of malfunctioning pro alpha 2(I) collagen genes in a patient with a pro alpha 2(1) chain - defective variant of Ehlers-Danlos syndrome. Eur F Biochem 1988;174:231-7.

69 Sasiki T, Gran K, Ono M, et al. Ehlers-Danlos syndrome: a variant characterised by the deficiency of the pro alpha 2 chain of type I procollagen. Arch Dermatol 1987;123:76-9.

70 Steinmann B, Tuderman L, Martin GR, et al. Evidence for structural mutation of procollagen type $I$ in a patient with Ehlers-Danlos syndrome type VII. Eur 7 Pediatr 1979;130: 203-5.

71 Steinmann B, Tuderman L, Peltonen L, et al. Evidence for a structural mutation of procollagen type $I$ in a patient with Ehlers-Danlos syndrome type VII. $\mathscr{f}$ Biol Chem 1980;255: Ehlers-D

72 Cole WG, Chan D, Chambers GW, et al. Deletion of 24 aminoacids from the pro alpha 1 (I) chain of type I procollagen in a patient with Ehlers-Danlos syndrome type VII. $f$ Biol Chem 1986;261:5496-503.

73 Cole WG, Evans R, Sillence DO. The clinical features of Ehlers-Danlos syndrome type VII due to a deletion of 24 amino acids from the pro alpha 1 (I) chain of type I procollagen. F Med Genet 1987;24:698-701.

74 Weil D, Bernard M, Combates N, et al. Identification of a mutation that causes exon-skipping during collagen pre-mRNA splicing in an EDS variant. $\mathcal{F}$ Biol Chem 1980;263:8561-4.

75 Weil D, D'Alessio M, Ramirez F, et al. Base substitution in the exon of a collagen gene causes alternative splicing and generates a structurally abnormal polypeptide in a patien with Ehlers-Danlos syndrome type VII. $E M B O \mathcal{f} 1989 ; 8$ : with Ehlers-

76 Weil D, D'Alessio M, Ramirez F, et al. Structural and functional characterisation of a splicing mutation in the pro alpha 2 (I) collagen gene of an Ehlers-Danlos syndrome type VII. F Biol Chem 1990;265:16007-11.

77 Weil D, D'Alessio M, Ramirez F, et al. Temperaturedependent expression of a collagen splicing defect in fibroblasts of a patient with Ehlers-Danlos syndrome type VII. F Biol Chem 1989;264:16804-9.

78 Nicholls AC, Oliver JE, Renouf DV, et al. Ehlers-Danlos syndrome type VII. A single base change that causes exon skipping in the type I collagen $\alpha 2$ (I) gene. Hum Genet 1991;87:183-98.

79 Vasan N, Kuivaniemi H, Vogel BE, et al. Mutation in the pro a2 (I) gene (COL1A2) for type I procollagen in $\alpha 2$ (I) gene (COL1A2) for type I procollagen in Ehlers-Danlos syndrome type VII. Evidence suggesting
that skipping of exon 6 in RNA splicing may be a common that skipping of exon 6 in RNA splicing may be a common
cause of the phenotype. Am $\mathcal{F}$ Hum Genet 1991;148:305-17.

cause of the phenotype. Am f Hum Genet 1991;148:305-17.
Watson RB, Wallis GA, Holmes DF, et al. Ehlers-Danlos Watson RB, Wallis GA, Holmes DF, et al. Ehlers-Danlos
syndrome type VII B; incomplete cleavage of abnormal type I procollagen by $\mathrm{N}$-proteinase in vitro results in the formation of copolymers of collagen and partially cleaved pNcollagen that are near-circular in cross-section. $\mathcal{F}$ Bio Chem 1996;257:9093.

81 Carr AJ, Chiodo AA, Hilton JM, et al. The clinical features of Ehlers-Danlos syndrome type VIIB resulting from a base COL1A1 gene. $₹$ Med Genet 1994;31:306-11.

82 Chiodo A, Hockey A, Cole WG. A base substitution at the splice acceptor site of intron 5 of the COL1A2 gene activates a cryptic splice site within exon 6 and generates activates a cryptic splice site within exon 6 and generates abnormal type I procollagen in a patient with Ehlers-
Danlos syndrome type VII. $\mathcal{F}$ Biol Chem 1991;267:6361-9.

Danlos syndrome type VII. F Biol Chem 1991;267:6361-9.
83 Ho KK, Kong RY, Kuffner T, et al. Further evidence that the failure to cleave the minor amino propeptide of type I procollagen is the cause of Ehlers-Danlos syndrome typ VII. Hum Mutat 1994;3:358-64.

84 Lehmann HW, Mandlos S, Winterpacht A, et al. EhlersDanlos syndrome type VII: phenotype and genotype. Arch Dermatol Res 1994;286:425-8.

85 Lapière CM, Lenaers A, Kohn LD. Procollagen peptidase: an enzyme excising the co-ordination peptides of procollagen. Proc Natl Acad Sci USA 1971;68:3054-8.

86 Lapiere CM, Nusgens BV. Ehlers-Danlos syndrome type VIIC or human dermatosparaxis. The offspring of a union between basic and clinical research. Arch Dermatol 1993;129:1316-19.

87 Nusgens BV, Verellen-Dumoulin CW, Hermanns-Le T, et al. Evidence for a relationship between Ehlers-Danlos synal. Evidence for a relationship between Ehlers-Danlos syndrome type VII C in hum

88 Smith LT, Wertelecki W, Milstone LM, et al. Human dermatosparaxis: a form of Ehlers-Danlos syndrome that results from failure to remove the amino-terminal propeptide type I procollagen. Am $\mathcal{F}$ Hum Genet 1992;51:235-44.

89 Reardon W, Winter RM, Smith LT, et al. The natural history of human dermatosparaxis (Ehlers-Danlos syndrome typ VII C). Clin Dysmorphol 1995;4:1-11.

90 Fjolstad M, Helle O. A hereditary dysplasia of collagen in sheep. F Pathol 1974;112:183-8.

91 Counts D, Byers PH, Holbrook KA, et al. Dermatosparaxi in a Himalayan cat. Biochemical studies of dermal collagen. $\mathcal{F}$ Invest Dermatol 1980;74:96-9.

92 Holmes DF, Watson RB, Steinmann B, et al. Ehlers-Danlo syndrome type VII B: morphology of type I collagen fibrils formed in vivo and in vitro is determined by the conformation of the retained N propeptide. F Biol Chem 1993;68: 15758-65.

93 Krane SM, Pinnell SR, Erbe RW. Lysyl procollagen hydroxylase deficiency in fibroblasts from siblings with hydroxylysine deficient collagen. Proc Natl Acad Sci USA 1972;69:2899-903.

94 Pinnell SR, Krane SM, Kenzora JE, et al. A heritable disorder of connective tissue: hydroxylysine deficient collagen. $N$ Engl f Med 1972;286:1013-20.

95 Myllyla R, Pihlajaniemi T, Pajunen R, et al. Molecular cloning of the chick lysyl hydroxylase: little homology in primary structure to the two types of subunit of prolyl 4-hydroxylase $\mathcal{F}$ Biol Chem 1991;266:2805-10.

96 Hautala T, Byers MG, Eddy RI, et al. Cloning of human lys hydroxylase: complete DNA-derived amino acid sequence and assignment of the gene (PLOD) to chromosome 1p36.3-36.2. Genomics 1992;13:62-9.

97 Yeowell HN, Walker LC, Marshall MK, et al. The mRNA and activity of lysyl hydroxylase are upregulated by the administration of ascorbate and hydroxlysine to human
skin fibroblasts from a patient with EDS VI. Arch Biochem skin fibroblasts from a patien
Biophys 1995;321:510-16.

$98 \mathrm{Ha} \mathrm{VT,} \mathrm{Marshal} \mathrm{MK,} \mathrm{Elsas} \mathrm{LJ,} \mathrm{et} \mathrm{al.} \mathrm{A} \mathrm{patient} \mathrm{with} \mathrm{Ehlers-}$ Danlos syndrome type VI is a compound heterozygote for mutations in the LOH gene. $\mathcal{F}$ Clin Invest 1993;93:1716-21.

99 Hautala T, Heikkinen J, Kivirikko KI, et al. A large duplication in the gene for lysyl hydroxylase accounts for the type VI variant of Ehlers-Danlos syndrome in two siblings. Genomics 1993;15:399-405.

100 Hyland J, Ala-Kokko L, Royce P, et al. A homozygous stop codon in the lysyl hydroxylase gene in two siblings with Ehlers-Danlos syndrome type VI. Nat Genet 1992;2:22831

101 Pousi B, Hautala T, Hakkinen J, et al. Alu-Alu recombination results in a duplication of seven exons in the lysyl hydroxylase gene in a patient with the type VI variant of Ehlers-Danlos syndrome. Am f Hum Genet 1994;55:899E06.

102 Heikkinen J, Hautala T, Kivirikko KI, et al. Structure and expression of the human lysyl hydroxylase gene (PLOD): introns 9 and 16 contain Alu sequences at the sites of recombination in EDS VI patients. Genomics 1994;24:464 71

103 Steinmann B, Eyre DR, Shao P. Urinary pyridinoline cross-links in Ehlers-Danlos syndrome type VI. Am f Hum Genet 1995;57:1505-8.

104 Pasquali M, Dembure PP, Still MT, et al. Urinary pyridinium cross-links: a non invasive diagnostic test for Ehlers-Danlos syndrome type VI. N Engl F Med 1994;331: 132-3.

105 Siegel R, Black CM, Bailey AJ. Cross-linking of collagen in the X-linked Ehlers-Danlos syndrome type V. Biochem Biophys Res Commun 1979;88:281-7.

$106 \mathrm{Di}$ Ferrante N, Leachman RD, Angelini P, et al. Ehlers-Danlos type V (X-linked form) a lysyl oxidase deficiency. Connect Tissue Res 1975;3:49-53.

107 Kessler E, Takahara K, Biniaminov L, et al. Bone morphogenetic protein 1: the type I procollagen $\mathrm{C}$-proteinase. Science 1996;271:360-2.

108 Reddi AH. BMP I: resurrection as procollagen C proteinase. Science (Perspectives) 1996;271:463.

109 Pope FM, Smith R. A colour atlas of inherited connective tissue disorders. New York: Mosby-Wolfe, 1996.

110 Stewart RE, Hollister DW, Rimoin DL. A new variant of Ehlers-Danlos syndrome: an autosomal dominant disorder of fragile skin, abnormal scarring and generalised periodontitis. Birth Defects 1977;XIII(3b):85-93.

111 Dyne KM, Vitellaro-Zuccarello L, Bacchella L, et al. Ehlers-Danlos syndrome type VIII: biochemical, stereological and immunocytochemical studies on dermis from a child with clinical signs of Ehlers-Danlos syndrome and a family history of premature loss of permanent teeth. $\mathrm{BrF}$ Dermatol 1993;128:458-63.

112 Hartsfield JK Jr, Kousseff BG. Phenotypic overlap of Ehlers-Danlos syndrome types IV and VIII. $A m \mathcal{f} M e d$ Genet 1990;37:465-70.

113 Lapière CM, Nusgens BV. Ehlers-Danlos syndrome (ED) type VIII skin has a reduced proportion of collagen III. $\mathcal{F}$ Invest Dermatol 1981;76:422A.

114 Nelson DL, King RA. Ehlers-Danlos syndrome type VIII. f Am Acad Dermatol 1981;5:297-303.

115 Lever WF. Histopathology of the skin. 4th ed. London: Pitman, 1967.

116 Arneson MA, Hammerschmidt DE, Furcht LT, et al. A new form of Ehlers-Danlos syndrome. 7 Am Med Assoc 1980;244:144-7.

117 Anstey A, Mayne K, Winter M, et al. Platelet and coagulation studies in Ehlers-Danlos syndrome. $\mathrm{Br} f$ Dermato 1992;125:155-63.

118 Pope FM, Nicholls AC, Palan A, et al. Clinical features of an affected father and daughter with Ehlers-Danlo syndrome type VII B. Brf Dermatol 1992;126:77-82. 